Original Research Article

\title{
A questionnaire based survey on knowledge, attitude and behaviour of antibiotic usage and resistance among undergraduates in South Indian teaching hospital
}

\author{
Nalinidevi Jayabalan, Nitya Selvaraj*, Suganya Ganesan, \\ Meher Ali Rajamohammad, Isswariya Anandan
}

Department of Pharmacology, Sri Manakula Vinayagar Medical College and Hospital, Puducherry, India

Received: 26 July 2018 Accepted: 30 August 2018

*Correspondence to: Dr. Nitya Selvaraj, Email: drnityapharm@ gmail.com

Copyright: () the author(s), publisher and licensee Medip Academy. This is an openaccess article distributed under the terms of the Creative Commons Attribution NonCommercial License, which permits unrestricted noncommercial use, distribution, and reproduction in any medium, provided the original work is properly cited.

\begin{abstract}
Background: Antibiotic resistance has become a global threat in the field of medicine. Multiple causes like antibiotic abuse, irrational usage of antibiotics, over the counter availability of antibiotics etc., have been put forth as culprit leading to antibiotic resistance. The present study aims at evaluating the knowledge, attitude and behaviour of antibiotic usage and resistance among undergraduates in South Indian teaching hospital.
\end{abstract}

Methods: A cross-sectional, questionnaire-based survey conducted in undergraduate MBBS students including $5^{\text {th }}$ to $9^{\text {th }}$ semester at Department of Pharmacology. The questionnaire comprised off: Demographic data; Knowledge including 12 questions using Four-point likert scale; Attitude and behaviours consisting of 8 questions of Yes/No type. Data were analysed in the software SPSS version 24.0. Association among categorical variable were analysed with Analysis of variance (ANOVA) followed by post hoc Bonferroni test.

Results: Among 455, 382 students completed the survey instrument and the response rate was $87 \%$. Statistically significant $(p=0.002)$ results have been obtained for the correct responses of knowledge questionnaire. The order of "good knowledge" about antibiotic usage and resistance according to semesters are graded as VIII $>$ VI $>$ V. Unfortunately, there were no significant results seen with attitude and behaviour.

Conclusions: The study concluded that, though there was adequate theoretical knowledge among undergraduate students however they lack in their attitude and behaviour regarding antibiotic usage and resistance. Therefore, they need to improve their attitude and behaviour over antibiotic usage and resistance.

Keywords: Antibiotic resistance, Knowledge and attitude, Questionnaire survey, Undergraduate MBBS students

\section{INTRODUCTION}

Antibiotic resistance is a major threat worldwide. ${ }^{1}$ Global utilization of antibiotic drugs elevated by $35 \%$ between 2000 and $2010 .^{2}$ Literature review revealed that there was high demand of antibiotic usage among low and middleincome countries. ${ }^{3}$

Self-medication is one of the commonest causes for the antibiotic resistance which is due to advises from families, friends, neighbours and the pharmacist, previous prescribed drug, or suggestions from the advertisement in newspapers or popular magazines etc. ${ }^{4}$ The common cause for antibiotic resistance may be due to antibiotic misuse which is also called as antibiotic abuse or overuse. Over the counter availability of antibiotics, low-socio economic status and antibiotic being sold without a prescription by pharmacists are also documented as reasons for antibiotic resistance. ${ }^{5}$

In addition to the as mentioned reasons, inadequate treatment duration, improper selection of drug and dosage 
also cause antibiotic resistance which urge to discover newer antibiotics to solve the antibiotic resistance. ${ }^{6,7}$ Less knowledge about antibiotic resistance among undergraduates, health care professionals, pharmacists lead to irrational usage of antibiotics among patients and is reported worldwide. ${ }^{5}$

Today's students are tomorrow's doctors. Hence in order to prevent antibiotic resistance, health care professionals should follow a rule of five rights of medication namely:

- $\quad$ Right drug

- Right patient

- Right dose

- Right duration

- Right route

And also, one should give a proper counselling about antibiotic usage and resistance. ${ }^{8}$

Further, a large number of foreign studies are available about knowledge, attitude, practice of antibiotic usage and resistance among undergraduates when compared to Indian studies. ${ }^{5,9-11}$ However periodic evaluation of usage of antibiotic knowledge is mandatory among health care professionals. This prompted me to evaluate knowledge, attitude and behaviour of antibiotic usage and resistance among undergraduate students.

The objective of the present research was to find out the level of Knowledge, Attitude and behaviour of antibiotic usage and resistance among the undergraduate students in South Indian Teaching Hospital

\section{METHODS}

A Structured self-administered questionnaire obtained from the work done by Scaioli et al, was given to the students after obtaining their informed written consent on a pure voluntary basis. ${ }^{11}$ Information about the study and instructions to complete the questionnaire were given to the study participants by the investigator. Questionnaire includes three major categories viz

- Demographic information

- Knowledge

- Attitude and Behaviors regarding antibiotic usage and resistance.

The demographic information included were age, gender, semester and relatives working in health-related fields. Knowledge included 12 questions which were of Fourpoint likert scale type (strongly agree, agree, disagree, strongly disagree). Attitude and behaviours consisted of 8 questions of Yes/No type.

\section{Statistical analysis}

Data was analysed in the software SPSS version 24.0. Description of categorical variables like gender, semester was mentioned in percentage. Data related to continuous variable like age were described in terms of mean and standard deviation. Association among categorical variables like semester, knowledge, attitude and behaviour were assessed by using one way ANOVA followed by post hoc analysis with Bonferroni test. ${ }^{12} \mathrm{P}$ value $<0.05$ was considered as statistically significant.

\section{RESULTS}

Total number of students from $5^{\text {th }}$ to $9^{\text {th }}$ semester were 455 . Out of 455 students, 382 had given voluntary consent and participated in this study. That showed a valid response rate which was $87 \%$.

Comparatively more number of females (52.9\%) had participated than males. Overall mean age was 20.7 \pm 1.4 . Particularly, the maximum respondents were from VI (33.5\%), compared to other semesters shown in Table 1. Students about $154(40.3 \%)$ confirmed at least one relative is working in health-related field.

Table 1: Demographic information of study participants.

\begin{tabular}{|c|c|c|}
\hline Demographic details & & $\begin{array}{l}\text { Total subjects } \\
(\mathrm{N}=382)\end{array}$ \\
\hline \multirow{5}{*}{ Age } & V Sem & $19 \pm 0.5$ \\
\hline & VI Sem & $20 \pm 0.5$ \\
\hline & VII Sem & $22 \pm 0.5$ \\
\hline & VIII Sem & $22 \pm 0.5$ \\
\hline & IX Sem & $23 \pm 0.5$ \\
\hline \multirow{2}{*}{ Gender } & Male & $180(47.1 \%)$ \\
\hline & Female & $202(52.9 \%)$ \\
\hline \multirow{5}{*}{ Semester } & $\mathrm{V}$ & $118(30.9 \%)$ \\
\hline & VI & $128(33.5 \%)$ \\
\hline & VII & $17(4.5 \%)$ \\
\hline & VIII & $104(27.2 \%)$ \\
\hline & IX & $15(3.9 \%)$ \\
\hline \multirow{2}{*}{$\begin{array}{l}\text { Relatives working in } \\
\text { health-related field }\end{array}$} & Yes & $154(40.3 \%)$ \\
\hline & No & $228(59.7 \%)$ \\
\hline
\end{tabular}

Categorical variables like Gender, Semester are mentioned in percentage and Continuous variable like age is described in terms of mean \pm standard deviation.

\section{Response about knowledge in antibiotic usage and resistance}

Participants revealed good knowledge about antibiotic usage and resistance. The correct response for each question considered as "strongly agree" or "strongly disagree" depending upon statement.

As shown in Table 2, among 382 students, 342 (89.5\%) strongly agreed that, penicillin is an antibiotic and more than $63 \%$ of medical students were aware that aspirin and paracetamol are not antibiotics. 
Regarding knowledge about antibiotic role, highest percentage of students $(83.5 \%)$ informed that, antibiotics were useful for treating bacterial infections but only lowest percentage of students i.e. $36 \%$ believed that antibiotics are not useful for viral infection and these drugs are not as same as anti-inflammatory agents.

With respect to knowledge about side-effects, only $40 \%$ of participants were conscious that "antibiotics can kill "good bacteria" present in our organism" and "antibiotics can cause allergic reactions" (44\% and $49.5 \%$ respectively) which leads to ill health. Very low percentage of students $(29.3 \%)$ strongly agreed that, antibiotics can cause secondary infections after killing good bacteria present in our organism. In response to knowledge about antibiotic resistance, fair amount of participants (71.7\%) informed that "Antibiotic resistance is a phenomenon for which a bacterium loses its sensitivity to an antibiotic". More than $60 \%$ of participants accepted that, misuse of antibiotics can lead to antibiotic resistance. Even then $46.9 \%$ of participants stopped antibiotics when symptoms improved. Therefore, there was a remarkable depth of knowledge seen among participants. The semester wise comparison was done with one-way ANOVA followed by post-hoc Bonferroni test revealed that, $\mathrm{V}$ semester compared with VIII shows $\mathrm{p}<0.05$, VI semester compared with VIII shows $\mathrm{p}<0.005$, VIII semester compared with $\mathrm{V}$ and VI shows $\mathrm{p}<0.05$ and $\mathrm{p}<0.005$ respectively.

Table 2: Knowledge regarding antibiotic usage and resistance among the participants.

\begin{tabular}{|c|c|c|c|c|c|c|c|}
\hline \multirow{2}{*}{ Topic } & \multirow{2}{*}{ Statement } & \multicolumn{5}{|c|}{ Semester (\%) } & \multirow{2}{*}{$\begin{array}{l}\mathbf{N}(\%) \\
\mathrm{n}=382\end{array}$} \\
\hline & & $\mathbf{V}$ & VI & VII & VIII & IX & \\
\hline \multirow[t]{3}{*}{$\begin{array}{l}\text { Identification } \\
\text { of antibiotics }\end{array}$} & $\begin{array}{l}\text { Penicillin is an antibiotic } \\
\text { Correct answer: Strongly agree }\end{array}$ & $\begin{array}{l}109 \\
(92.4 \%)\end{array}$ & $\begin{array}{l}113 \\
(88.3 \%)\end{array}$ & $\begin{array}{l}13 \\
(76.5 \%)\end{array}$ & $\begin{array}{l}94 \\
(90.4 \%)\end{array}$ & $\begin{array}{l}13 \\
(86.7 \%)\end{array}$ & $\begin{array}{l}342 \\
(89.5 \%)\end{array}$ \\
\hline & $\begin{array}{l}\text { Aspirin is an antibiotic } \\
\text { Correct answer: Strongly disagree }\end{array}$ & $\begin{array}{l}69 \\
(58.5 \%)\end{array}$ & $\begin{array}{l}70 \\
(54.7 \%)\end{array}$ & $\begin{array}{l}9 \\
(52.9 \%)\end{array}$ & $\begin{array}{l}82 \\
(78.8 \%)\end{array}$ & $\begin{array}{l}11 \\
(73.3 \%)\end{array}$ & $\begin{array}{l}241 \\
(63.1)\end{array}$ \\
\hline & $\begin{array}{l}\text { Paracetamol is an antibiotic } \\
\text { Correct answer: Strongly disagree }\end{array}$ & $\begin{array}{l}72 \\
(61.0 \%)\end{array}$ & $\begin{array}{l}75 \\
(58.6 \%)\end{array}$ & $\begin{array}{l}9 \\
(52.9 \%)\end{array}$ & $\begin{array}{l}79 \\
(76.0 \%)\end{array}$ & $\begin{array}{l}10 \\
(66.7 \%)\end{array}$ & $\begin{array}{l}245 \\
(64.1 \%)\end{array}$ \\
\hline \multirow{3}{*}{$\begin{array}{l}\text { Knowledge } \\
\text { about } \\
\text { antibiotic role }\end{array}$} & $\begin{array}{l}\text { Antibiotics are useful for bacterial } \\
\text { infections } \\
\text { Correct answer: Strongly agree }\end{array}$ & $\begin{array}{l}95 \\
(80.5 \%)\end{array}$ & $\begin{array}{l}106 \\
(82.8 \%)\end{array}$ & $\begin{array}{l}14 \\
(82.4 \%)\end{array}$ & $\begin{array}{l}92 \\
(88.5 \%)\end{array}$ & $\begin{array}{l}12 \\
(80.0 \%)\end{array}$ & $\begin{array}{l}319 \\
(83.5 \%)\end{array}$ \\
\hline & $\begin{array}{l}\text { Antibiotics are useful for viral } \\
\text { infections } \\
\text { Correct answer: Strongly disagree }\end{array}$ & $\begin{array}{l}43 \\
(36.4 \%)\end{array}$ & $\begin{array}{l}39 \\
(30.5 \%)\end{array}$ & $\begin{array}{l}4 \\
(23.5 \%)\end{array}$ & $\begin{array}{l}50 \\
(48.1 \%)\end{array}$ & $\begin{array}{l}3 \\
(20.0 \%)\end{array}$ & $\begin{array}{l}139 \\
(36.4 \%)\end{array}$ \\
\hline & $\begin{array}{l}\text { Antibiotics are the same as anti- } \\
\text { inflammatory agents } \\
\text { Correct answer: Strongly disagree }\end{array}$ & $\begin{array}{l}44 \\
(37.3 \%)\end{array}$ & $\begin{array}{l}36 \\
(28.1 \%)\end{array}$ & $\begin{array}{l}7 \\
(41.2 \%)\end{array}$ & $\begin{array}{l}44 \\
(42.3 \%)\end{array}$ & $\begin{array}{l}10 \\
(66.7 \%)\end{array}$ & $\begin{array}{l}141 \\
(36.9 \%)\end{array}$ \\
\hline \multirow{3}{*}{$\begin{array}{l}\text { Knowledge } \\
\text { about side- } \\
\text { effects }\end{array}$} & $\begin{array}{l}\text { Antibiotics can kill "good bacteria" } \\
\text { present in our organism } \\
\text { Correct answer: Strongly agree }\end{array}$ & $\begin{array}{l}49 \\
(41.5 \%)\end{array}$ & $\begin{array}{l}54 \\
(42.2 \%)\end{array}$ & $\begin{array}{l}11 \\
(64.7 \%)\end{array}$ & $\begin{array}{l}50 \\
(48.1 \%)\end{array}$ & $\begin{array}{l}4 \\
(26.7 \%)\end{array}$ & $\begin{array}{l}168 \\
(44.0 \%)\end{array}$ \\
\hline & $\begin{array}{l}\text { Antibiotics can cause secondary } \\
\text { infections after killing good } \\
\text { bacteria present in our organism } \\
\text { Correct answer: Strongly agree }\end{array}$ & $\begin{array}{l}28 \\
(23.7 \%)\end{array}$ & $\begin{array}{l}43 \\
(33.6 \%)\end{array}$ & $\begin{array}{l}4 \\
(23.5 \%)\end{array}$ & $\begin{array}{l}34 \\
(32.7 \%)\end{array}$ & $\begin{array}{l}3 \\
(20.0 \%)\end{array}$ & $\begin{array}{l}112 \\
(29.3 \%)\end{array}$ \\
\hline & $\begin{array}{l}\text { Antibiotics can cause allergic } \\
\text { reactions } \\
\text { Correct answer: Strongly agree }\end{array}$ & $\begin{array}{l}69 \\
(58.5 \%)\end{array}$ & $\begin{array}{l}50 \\
(39.1 \%)\end{array}$ & $\begin{array}{l}7 \\
(41.2 \%)\end{array}$ & $\begin{array}{l}57 \\
(54.8 \%)\end{array}$ & $\begin{array}{l}6 \\
(40.0 \%)\end{array}$ & $\begin{array}{l}189 \\
(49.5 \%)\end{array}$ \\
\hline \multirow{3}{*}{$\begin{array}{l}\text { Knowledge } \\
\text { about } \\
\text { antibiotic } \\
\text { resistance }\end{array}$} & $\begin{array}{l}\text { Antibiotic resistance is a } \\
\text { phenomenon for which a bacterium } \\
\text { loses its sensitivity to an antibiotic } \\
\text { Correct answer: Strongly agree }\end{array}$ & $\begin{array}{l}82 \\
(69.5 \%)\end{array}$ & $\begin{array}{l}97 \\
(75.8 \%)\end{array}$ & $\begin{array}{l}8 \\
(47.1 \%)\end{array}$ & $\begin{array}{l}77 \\
(74.0 \%)\end{array}$ & $\begin{array}{l}10 \\
(66.7 \%)\end{array}$ & $\begin{array}{l}274 \\
(71.7 \%)\end{array}$ \\
\hline & $\begin{array}{l}\text { Misuse of antibiotics can lead to } \\
\text { antibiotic resistance } \\
\text { Correct answer: Strongly agree }\end{array}$ & $\begin{array}{l}62 \\
(52.5 \%)\end{array}$ & $\begin{array}{l}86 \\
(67.2 \%)\end{array}$ & $\begin{array}{l}10 \\
(58.8 \%)\end{array}$ & $\begin{array}{l}84 \\
(80.8 \%)\end{array}$ & $\begin{array}{l}8 \\
(53.3 \%)\end{array}$ & $\begin{array}{l}250 \\
(65.4 \%)\end{array}$ \\
\hline & $\begin{array}{l}\text { It is okay to stop taking antibiotic } \\
\text { when symptoms are improving } \\
\text { Correct answer: Strongly disagree }\end{array}$ & $\begin{array}{l}58 \\
(49.2 \%)\end{array}$ & $\begin{array}{l}47 \\
(36.7 \%)\end{array}$ & $\begin{array}{l}6 \\
(35.3 \%)\end{array}$ & $\begin{array}{l}61 \\
(58.7 \%)\end{array}$ & $\begin{array}{l}7 \\
(46.7 \%)\end{array}$ & $\begin{array}{l}179 \\
(46.9 \%)\end{array}$ \\
\hline
\end{tabular}

Values are expressed as frequencies and percentages. $n=$ Total number of participants, Frequency and percentage of participants who gave correct response based on semester of study 
Table 3: Frequency and percentage of knowledge scores among study participants.

\begin{tabular}{|llll|}
\hline Semester & No. of participants (Total = 382) & $\begin{array}{l}\text { Frequency and percentage Total=216 } \\
(\mathbf{5 7 \%})\end{array}$ & P-value \\
\hline Fifth semester & 118 & $65(55 \%)$ & $\mathrm{F}=4.359$ \\
\hline Six semester & 128 & $68(53 \%)$ & $\mathrm{P}=0.002$ \\
\hline Seventh semester & 17 & $8.5(50 \%)$ & $67(64 \%)$ \\
\hline Eighth semester & 104 & $8(54 \%)$ & \\
\hline Ninth semester & 15 & 6 & \\
\hline
\end{tabular}

Knowledge compared with V, VI, VII, VIII and IX semesters by using one-way ANOVA followed by post-hoc analysis with Bonferroni test. $\mathrm{P}$ value $<0.05$ was considered as statistically significant.

Table 4: Attitude and behavior regarding antibiotic usage and resistance among the participants.

\begin{tabular}{|c|c|c|c|c|c|c|}
\hline \multirow{2}{*}{ Statement } & \multicolumn{5}{|c|}{ Semester $(\%)$} & \multirow{2}{*}{$\begin{array}{l}\mathbf{N}(\%) \\
\mathbf{n}=382\end{array}$} \\
\hline & $\mathbf{V}$ & VI & VII & VIII & IX & \\
\hline $\begin{array}{l}\text { Do you usually take antibiotics for cold or sore } \\
\text { throat? } \\
\text { Correct answer: No }\end{array}$ & $\begin{array}{l}65 \\
(55.1 \%)\end{array}$ & $\begin{array}{l}49 \\
(38.3 \%)\end{array}$ & $\begin{array}{l}7 \\
(41.2 \%)\end{array}$ & $\begin{array}{l}62 \\
(59.6 \%)\end{array}$ & $\begin{array}{l}8 \\
(53.3 \%)\end{array}$ & $\begin{array}{l}191 \\
(50.0 \%)\end{array}$ \\
\hline $\begin{array}{l}\text { Do you usually take antibiotics for fever? } \\
\text { Correct answer: No }\end{array}$ & $\begin{array}{l}73 \\
(61.9 \%)\end{array}$ & $\begin{array}{l}76 \\
(59.4 \%)\end{array}$ & $\begin{array}{l}8 \\
(47.1 \%)\end{array}$ & $\begin{array}{l}66 \\
(63.5 \%)\end{array}$ & $\begin{array}{l}13 \\
(86.7 \%)\end{array}$ & $\begin{array}{l}236 \\
(61.8 \%)\end{array}$ \\
\hline $\begin{array}{l}\text { Do you usually stop taking antibiotic when you } \\
\text { start feeling better? } \\
\text { Correct answer: No }\end{array}$ & $\begin{array}{l}59 \\
(50.0 \%)\end{array}$ & $\begin{array}{l}71 \\
(55.5 \%)\end{array}$ & $\begin{array}{l}7 \\
(41.2 \%)\end{array}$ & $\begin{array}{l}58 \\
(55.8 \%)\end{array}$ & $\begin{array}{l}9 \\
(60.0 \%)\end{array}$ & $\begin{array}{l}204 \\
(53.4 \%)\end{array}$ \\
\hline $\begin{array}{l}\text { Do you take antibiotics only when prescribed } \\
\text { by the doctor? } \\
\text { Correct answer: Yes }\end{array}$ & $\begin{array}{l}89 \\
(75.4 \%)\end{array}$ & $\begin{array}{l}89 \\
(69.5 \%)\end{array}$ & $\begin{array}{l}11 \\
(64.7 \%)\end{array}$ & $\begin{array}{l}58 \\
(55.8 \%)\end{array}$ & $\begin{array}{l}12 \\
(80.0 \%)\end{array}$ & $\begin{array}{l}259 \\
(67.8 \%)\end{array}$ \\
\hline $\begin{array}{l}\text { Do you have leftover antibiotics at home? } \\
\text { Correct answer: No }\end{array}$ & $\begin{array}{l}62 \\
(52.5 \%)\end{array}$ & $\begin{array}{l}60 \\
(46.9 \%)\end{array}$ & $\begin{array}{l}7 \\
(41.2 \%)\end{array}$ & $\begin{array}{l}52 \\
(50.0 \%)\end{array}$ & $\begin{array}{l}9 \\
(60.0 \%)\end{array}$ & $\begin{array}{l}190 \\
(49.7 \%)\end{array}$ \\
\hline $\begin{array}{l}\text { Do you use leftovers antibiotics when you have } \\
\text { cold, sore throat or flu without consulting your } \\
\text { doctor? } \\
\text { Correct answer: No }\end{array}$ & $\begin{array}{l}78 \\
(66.1 \%)\end{array}$ & $\begin{array}{l}81 \\
(63.3 \%)\end{array}$ & $\begin{array}{l}11 \\
(64.7 \%)\end{array}$ & $\begin{array}{l}71 \\
(68.3 \%)\end{array}$ & $\begin{array}{l}14 \\
(93.3 \%)\end{array}$ & $\begin{array}{l}255 \\
(66.8 \%)\end{array}$ \\
\hline $\begin{array}{l}\text { Do you buy antibiotics without medical } \\
\text { prescription? } \\
\text { Correct answer: No }\end{array}$ & $\begin{array}{l}67 \\
(56.8 \%)\end{array}$ & $\begin{array}{l}65 \\
(50.8 \%)\end{array}$ & $\begin{array}{l}6 \\
(35.3 \%)\end{array}$ & $\begin{array}{l}54 \\
(51.9 \%)\end{array}$ & $\begin{array}{l}9 \\
(60.0 \%)\end{array}$ & $\begin{array}{l}201 \\
(52.6 \%)\end{array}$ \\
\hline $\begin{array}{l}\text { Do you start taking antibiotics only after a } \\
\text { phone call with your doctor? } \\
\text { Correct answer: Yes }\end{array}$ & $\begin{array}{l}54 \\
(45.8 \%)\end{array}$ & $\begin{array}{l}73 \\
(57.0 \%)\end{array}$ & $\begin{array}{l}9 \\
(52.9 \%)\end{array}$ & $\begin{array}{l}47 \\
(45.2 \%)\end{array}$ & $\begin{array}{l}10 \\
(66.7 \%)\end{array}$ & $\begin{array}{l}193 \\
(50.3 \%)\end{array}$ \\
\hline
\end{tabular}

Values are expressed as frequencies and percentages. $n=$ Total number of participants. Frequency and percentage of participants who gave correct response based on semester of study.

Therefore, significant results obtained from knowledge of participants $(\mathrm{p}=0.002)$ as depicted in Table 3 . The order of "good knowledge" about antibiotic usage and resistance according to semesters are graded as VIII $>$ VI $>$ V .

\section{Response about attitude and behaviours}

As illustrated in Table 4, Out of 382 students, $50 \%$ of participants opined that they won't take antibiotics for cold, sore throat and for fever $(61.8 \%)$. More than $50 \%$ of students refused to stop taking antibiotics which was advised by the clinician when they feel better and good number of students $(67.8 \%)$ took antibiotics only when prescribed by doctor. About $49.7 \%$ of students did not have leftover antibiotics at home. Comparatively $66.8 \%$ of students relayed that leftover antibiotics should not be taken when they had cold, sore throat or flu without consulting a doctor.

"Buying antibiotics without medical prescription" and "Start taking antibiotics only after a telephonic conversation with the doctor" were accepted by $52.6 \%$ and $50.3 \%$ of participants respectively. The results were analysed by using one way ANOVA followed by post-hoc test shows no significance as given in Table 5.

\section{DISCUSSION}

The augmented etiology for antibiotic resistance being poor prescription practices, self-medication, incorrect or 
inappropriate usage of antibiotics, antibiotic abuse, over the counter availability of antibiotics. ${ }^{6}$ Henceforth the present study was aimed at assessing knowledge, attitude and behaviour of antibiotic resistance and usage among undergraduates in South Indian Teaching Hospital.

Table 5: Frequency and percentage of attitude and behaviours scores among study participants.

\begin{tabular}{|c|c|c|c|}
\hline Semester & $\begin{array}{l}\text { Number of participants } \\
\text { Total=382 }\end{array}$ & Frequency and percentage Total=216(57\%) & P-value \\
\hline Fifth semester & 118 & $68.3(58 \%)$ & \multirow{5}{*}{$\begin{array}{l}F=1.328 \\
P=0.259\end{array}$} \\
\hline Six semester & 128 & $70.5(55 \%)$ & \\
\hline Seventh semester & 17 & $8.2(48.5 \%)$ & \\
\hline Eighth semester & 104 & $51(56 \%)$ & \\
\hline Ninth semester & 15 & $10.5(70 \%)$ & \\
\hline
\end{tabular}

Attitude and behavior compared with V, VI, VII, VIII and IX semesters by using one way ANOVA followed by post-hoc analysis with Bonferroni test. $\mathrm{P}$ value $<0.05$ was considered as statistically significant.

In this present study, among 382 students, $89.5 \%$ and more than $63 \%$ were aware that penicillin is an antibiotic and aspirin and paracetamol are not antibiotics respectively. However, study done by Scaioli $\mathrm{G}$ et al, yielded better result of $96 \%$ and $95 \%$ respectively when same questions were asked to the participants. ${ }^{11}$ Likewise present study revealed that majority of them $(83.5 \%)$ were aware that antibiotics are useful for treating bacterial infections which is in accordance with a study done by Gary S et al, showing $70 \%$ positive response in medical students. ${ }^{13}$

But surprisingly $36.4 \%$ and $36.9 \%$ strongly disagreed that, antibiotics are useful for viral infections and they are same as anti-inflammatory agents. Similar results had been obtained from the study done by Huang Y et al, among 2500 Chinese medical students. ${ }^{14}$ Thus in order to rectify this lacuna, authors need to clearly emphasize the undergraduate medical students regarding the usage of antibiotics and also its pharmacological actions which can help them to practice in a better way.

It is also necessary for undergraduates to have clear knowledge regarding the adverse reactions caused by antibiotics. In the present study, $49.5 \%$ and $65.4 \%$ of students believed that antibiotic caused allergic reactions and misuse of antibiotics lead to antibiotic resistance respectively. Another study done by Gary $\mathrm{S}$ et al, had shown similar result and also stated that, misuse and inappropriate usage of antibiotic causes ill health. ${ }^{13}$

In fact the study revealed that, $80 \%$ of students believed that taking higher class of antibiotics for milder infections can lead to antibiotic resistance. ${ }^{10}$ Thriemer $\mathrm{K}$ et al, said that most of the participants agreed or strongly agreed that, antibiotic resistance occurred due to over usage of antibiotics which was in accordance with our study. ${ }^{15}$

With the availability of many antibiotics, it is necessary for the doctors to prescribe appropriate antibiotics in order to prevent emerging resistance pattern and it is a good sign that the study participants had good knowledge about inappropriate usage of higher antibiotics.

Another major causative leading to resistance is noncompliance especially when symptoms disappear patients tend to stop medication paving way for antibiotic resistance. Nearly $46.9 \%$ were aware of the fact that antibiotics should not be stopped when symptoms were improving, in our study. A study conducted at Italy in general population by Napolitano F et al, had shown that, $50 \%$ of people were aware of the fact that incomplete antibiotic course can lead to lack of effectiveness. ${ }^{16}$

However, considering semester wise knowledge, VIII semester students were having good knowledge over identification of antibiotics and antibiotic role compared to all other semesters. Comparatively IX semester students were having lowest knowledge on side effects. Whereas VI and VIII semester produced fair responses over knowledge about antibiotic resistance. The order of "good knowledge" about antibiotic usage and resistance according to semester were graded as VIII $>$ VI $>$ V. This shows that the knowledge has considerably increased as they reach higher semester and the reason could be simultaneous clinical exposure which added more to theoretical knowledge of study participants.

Several studies done across the world on antibiotic usage and resistance listed that there was a lack of knowledge about antibiotic prescription and students need education about appropriate prescribing. ${ }^{17-19}$ Even in the present study authors obtained poor response for some basic questions. So, there is an ever-ending quest to update the knowledge regarding antibiotic usage among undergraduates throughout their study period.

There is a lot of gap between knowledge and attitude. Fortunately, in the present study when questions regarding attitude were asked, $49.7 \%$ and $66.8 \%$ of participants stated that left over antibiotics should not be taken and also 
antibiotics should not be taken for cold, sore throat or flu without consulting doctor respectively. Similar results regarding left over antibiotics usage had been obtained from studies done by Scaioli G et al, in Italy and Gary S et al, in Jordan, but latter study had also shown that significant number of students had taken antibiotic without consultation with the doctor. Even though they have discussed about medication use, most of the students agreed that they changed the dose and duration on their own without the knowledge of doctor. ${ }^{6,11}$ In this study, about $204(53.4 \%)$ students refused to stop taking antibiotics when they feel better. $259(67.8 \%)$ students had taken antibiotics only when prescribed by the doctor. Similar results have been obtained from study done by Hsiao FY et al, among Taiwan students, but comparatively less number of students agreed in accordance with present study. ${ }^{19}$

Present study findings show that, $50 \%$ of students won't take antibiotics for cold, sore throat and 236 (61.8\%) for fever. Remaining students believed that, antibiotic usage for these minor ailments lead to decrease in the course of illness and also caused better improvement. This misconception may be one of the reasons why antibiotics causes resistance. Similar results have been obtained from the study done by Mukharjee SK et al, and Khan AK et al. ${ }^{20,21}$

Present study depicted that, knowledge, attitude and behavior among undergraduate, produced a drastic difference as the semester increased (i.e. VIII semester gave good response when compared to VI $>$ V semester) due to clinical knowledge and exposure, but there was a slight lacuna seen over IX semester on antibiotic usage and resistance.

To achieve a target, intervention like special courses, workshops, conferences, group discussion should be conducted to improve appropriate antibiotic prescription practice for each year after they completed II-year MBBS. In fact, classes regarding antibiotic usage and resistance must be incorporated in third and final years if possible. Antibiotic misuse by the junior doctors can cause impact on the behaviour of antibiotic usage and resistance. Hence improving knowledge, attitude and behaviour of undergraduate is necessary and mandatory. ${ }^{14,15}$

The limitations of the present study were the gold standard method of survey was face-to-face interview which can be incorporated in future studies to get better results. Survey was done only with limited number of participants. Study was done in single institution. Self-administered questionnaire can lead to recall bias.

\section{CONCLUSION}

The study concluded that, though there was adequate theoretical knowledge among undergraduate students however they lack in their attitude and behaviour regarding antibiotic usage and resistance. Therefore, they need to improve their attitude and behaviour over antibiotic usage and resistance. To enhance the overall knowledge and attitude about antibiotics, students need special courses of education over rational prescription of antibiotics that highlight more on behaviour of undergraduate students towards antibiotic usage and resistance instead of improving knowledge alone.

\section{ACKNOWLEDGEMENTS}

Authors would like to thank authorities of Sri Manakula Vinayagar Medical College and Hospital and also acknowledge the Epidemiology unit of Department of Community Medicine for their support.

Funding: No funding sources

Conflict of interest: None declared

Ethical approval: The study was approved by the Institutional Ethics Committee

\section{REFERENCES}

1. Kumar SG, Adithan C, Harish BN, Sujatha S, Roy G, Malini A. Antimicrobial resistance in India: a review. J Natural Sci Bio Med. 2013 Jul;4(2):286.

2. Van Boeckel TP, Gandra S, Ashok A, Caudron Q, Grenfell BT, Levin SA, et al. Global antibiotic consumption 2000 to 2010: an analysis of national pharmaceutical sales data. Lancet Infect Dis. 2014 Aug 1;14(8):742-50.

3. Ocan M, Obuku EA, Bwanga F, Akena D, Richard S, Ogwal-Okeng J, et al. Household antimicrobial selfmedication: a systematic review and meta-analysis of the burden, risk factors and outcomes in developing countries. BMC Public Health. 2015 Dec;15(1):742.

4. Bennadi D. Self-medication: A current challenge. J Basic Clin Pharm. 2013 Dec;5(1):19.

5. Ghaieth MF, Elhag SR, Hussien ME, Konozy EH. Antibiotics self-medication among medical and nonmedical students at two prominent Universities in Benghazi City, Libya. J Pharma Bioallied Sci. 2015 Apr;7(2):109.

6. Ventola CL. The antibiotic resistance crisis: part 1: causes and threats. Pharma Therapeut. 2015 Apr;40(4):277.

7. Bahnassi A. A qualitative analysis of pharmacists' attitudes and practices regarding the sale of antibiotics without prescription in Syria. J Taibah Uni Med Sci. 2015 Jun 1;10(2):227-33.

8. Lee CR, Cho IH, Jeong BC, Lee SH. Strategies to minimize antibiotic resistance. Int J Environment Res Public Health. 2013 Sep 12;10(9):4274-305.

9. Sharma S, Jayakumar D, Palappallil DS, Kesavan KP. Knowledge, attitude and practices of antibiotic usage and resistance among the second year MBBS Students. Int J Basic Clin Pharmacol. 2016;5(3):899903.

10. Rajiah K, Ren WS, Jamshed SQ. Evaluation of the understanding of antibiotic resistance among Malaysian pharmacy students at public universities: an 
exploratory study. J Infect Public Health. 2015 May 1;8(3):266-73.

11. Scaioli G, Gualano MR, Gili R, Masucci S, Bert F, Siliquini R. Antibiotic use: a cross-sectional survey assessing the knowledge, attitudes and Practices amongst Students of a School of Medicine in Italy. PLoS One. 2015 Apr 1;10(4):e0122476.

12. Yadav T, Arya K, Kataria D, Balhara YP. Impact of psychiatric education and training on attitude of medical students towards mentally ill: a comparative analysis. Industrial Psychiatry J. 2012 Jan;21(1):22.

13. Suaifan GA, Shehadeh M, Darwish DA, Al-Ije H, Yousef AM, Darwish RM. A cross-sectional study on knowledge, attitude and behavior related to antibiotic use and resistance among medical and non-medical university students in Jordan. African J Pharmacy Pharmacol. 2012 Mar 15;6(10):763-70.

14. Huang Y, Gu J, Zhang M, Ren Z, Yang W, Chen Y, et al. Knowledge, attitude and practice of antibiotics: a questionnaire study among 2500 Chinese students. BMC Med Education. 2013 Dec;13(1):163.

15. Thriemer K, Katuala Y, Batoko B, Alworonga JP, Devlieger H, Van Geet C, et al. Antibiotic prescribing in DR Congo: a knowledge, attitude and practice survey among medical doctors and students. PloS One. 2013 Feb 18;8(2):e55495.

16. Napolitano F, Izzo MT, Di Giuseppe G, Angelillo IF. Public knowledge, attitudes, and experience regarding the use of antibiotics in Italy. PloS One. 2013 Dec 23;8(12):e84177.

17. Dyar OJ, Howard P, Nathwani D, Pulcini C. Knowledge, attitudes, and beliefs of French medical students about antibiotic prescribing and resistance. Med Mal Infect. 2013 Oct 1;43(10):423-30.

18. Wasserman S, Potgieter S, Shoul E, Constant D, Stewart A, Mendelson M, et al. South African medical students' perceptions and knowledge about antibiotic resistance and appropriate prescribing: Are we providing adequate training to future prescribers? South African Med J. 2017;107(5):405-10.

19. Hsiao FY, Lee JA, Huang WF, Chen SM, Chen HY. Survey of medication knowledge and behaviors among college students in Taiwan. Am J Pharma Education. 2006 Sep;70(2):30.

20. Mukharjee SK, Mahmud I, Akter S, Hossain S. Knowledge, attitudes and practices regarding antibiotic use among the students of microbiology department at Noakhali science and technology university, Bangladesh. J Drug Delivery Therapeutics. 2017 Jul 15;7(4):34-7.

21. Afzal Khan AK, Banu G, Reshma KK. Antibiotic resistance and usage-a survey on the knowledge, attitude, perceptions and practices among the medical students of a Southern Indian teaching hospital. JCDR. 2013 Aug;7(8):1613.

Cite this article as: Jayabalan N, Selvaraj N, Ganesan S, Rajamohammad MA, Anandan I. A questionnaire based survey on knowledge, attitude and behaviour of antibiotic usage and resistance among undergraduates in South Indian teaching hospital. Int J Basic Clin Pharmacol 2018;7:1991-7. 